\title{
INVENTARISASI PARASITOID HAMA PENGGULUNG DAUN PISANG (Erionota thrax L.) DI KABUPATEN LAMPUNG SELATAN
}

\author{
Imelda Tita Pratiwi, Lestari Wibowo, Indriyati \& Purnomo \\ Jurusan Agroteknologi, Fakultas Pertanian Universitas Lampung \\ J1. Prof. Dr. Soemantri Brodjonegoro no. 1 Bandar Lampung 35145 \\ Email:imeldatita@yahoo.co.id
}

\begin{abstract}
ABSTRAK
Penelitian ini bertujuan untuk menginventarisasi parasitoid hama penggulung daun pisang (E. thrax L.) dan menghitung persentase parasitasinya di Kabupaten Lampung Selatan. Penelitian ini dilakukan dengan menggunakan metode survei dan pengamatan di laboratorium. Pengambilan sampel dilakukan pada sembilan desa di tiga kecamatan. Hasil penelitian menunjukkan bahwa parasitoid yang ditemukan di Kabupaten Lampung Selatan adalah Braconidae (Cotesia sp.), Chalcididae (Brachymeria sp.), Tachinidae (A), Ichneumonidae (A) (Charops sp.), Ichneumonidae (B), Tachinidae (B), Pteromalidae, dan Ichneumonidae (C) (Xanthopimpla sp.). Rata-rata persentase parasitasi terhadap hama penggulung daun pisang tertinggi adalah pada Kecamatan Tanjung Bintang yaitu sebesar 55,00\%, sedangkan pada Kecamatan Jati Agung dan Natar masing-masing sebesar $36,67 \%$ dan $28,33 \%$.
\end{abstract}

Kata Kunci : Erionota thrax, parasitoid, persentase parasitasi.

\section{PENDAHULUAN}

Pisang merupakan buah yang memiliki kandungan gizi yang sangat beragam dan diperlukan oleh tubuh. Gizi yang terdapat dalam buah pisang antara lain karbohidrat, protein, lemak, provitamin A, vitamin B, B1, B2, B6, B12, dan vitamin C. Selain itu pisang sangat kaya mineral seperti kalium, magnesium, fosfor, kalsium, dan zat besi (Harlinawati, 2006). Menurut BPS Lampung (2007), Kabupaten Lampung Selatan merupakan penghasil pisang terbesar di Provinsi Lampung, dilanjutkan dengan Kabupaten Lampung Timur dan Way Kanan. Salah satu masalah yang sering dihadapi oleh para petani pisang adalah masalah hama dan penyakit yang menyerang tanaman. Salah satu hama yang sering menyerang tanaman pisang adalah hama penggulung daun pisang (Erionota thrax L.) (Satuhu \& Supriyadi, 2007). Pengendalian hama penggulung daun pisang dapat dilakukan dengan cara mekanik atau dengan cara kimia, namun kedua cara ini kurang efektif dilakukan sehingga perlu adanya pengendalian lain yang dapat dipadukan dalam mengendalikan hama penggulung daun pisang yaitu pengendalian hayati atau pengendalian biologi.

Pengendalian hayati adalah pengendalian hama dengan memanfaatkan musuh alami yang berada di alam. Salah satu musuh alami yang dapat dimanfaatkan untuk mengendalikan hama adalah parasitoid. Parasitoid adalah serangga yang hidup menjadi parasit di dalam atau pada tubuh serangga lain, dan membunuhnya secara pelan-pelan (Direktorat Perlindungan Perkebunan, 2002). Penelitian ini bertujuan untuk menginventarisasi parasitoid hama penggulung daun pisang (Erionota thrax L.) dan menghitung persentase parasitasinya di Kabupaten Lampung Selatan.

\section{BAHAN DAN METODE}

Penelitian ini dilaksanakan dalam dua kegiatan. Kegiatan pertama yaitu pengambilan sampel hama penggulung daun pisang di lapangan. Pengambilan sampel dilaksanakan di Kabupaten Lampung Selatan, pada tiga kecamatan yaitu Kecamatan Natar, Jati Agung, dan Tanjung Bintang. Kegiatan kedua yaitu mengamati dan mengidentifikasi parasitoid yang diperoleh dari hama penggulung daun pisang, yang dilaksanakan di Laboratorium Hama, Fakultas Pertanian, Universitas Lampung. Identifikasi dilakukan sampai famili, namun jika dimungkinkan dilanjutkan sampai genus atau spesies. Penelitian ini dilaksanakan pada bulan Desember 2013 sampai dengan Februari 2014.

Penelitian inventarisasi parasitoid pada hama penggulung daun pisang dilaksanakan dengan menggunakan metode survei. Metode ini dilaksanakan 
dengan mengambil sampel hama penggulung daun pisang yang dilakukan secara acak di Kabupaten Lampung Selatan pada tiga kecamatan yaitu Kecamatan Natar, Jati Agung, dan Tanjung Bintang.

Stoples pemeliharaan yang diperlukan adalah stoples dengan ketinggian $22 \mathrm{~cm}$, diameter $8 \mathrm{~cm}$, transparan, serta mudah dibuka dan ditutup saat pengamatan. Pembuatan stoples pemeliharaan dilakukan dengan menggunakan dua buah gelas plastik yang biasa digunakan untuk minuman jus. Salah satu alas dari gelas tersebut dilubangi, lalu ditempelkan kain kasa sebagai penutup alas gelas tersebut. Setelah itu, bagian atas gelas dipotong sampai gelas tersebut dapat menyatu dengan gelas yang lain dengan keadaan rapat.

Sampel yang diambil adalah bagian daun pisang yang terserang hama penggulung daun pisang. Sampel tersebut diambil dari Kecamatan Natar yang terdiri dari Desa Candimas, Bumi Sari, dan Tanjung Sari. Kecamatan Tanjung Bintang terdiri dari Desa Rejomulyo, Sindang Sari, dan Purwodadi Simpang. Kecamatan Jati Agung terdiri dari Desa Rejomulyo, Karang Anyar, dan Fajar Baru. Setiap sampel gulungan daun pisang yang diperoleh dari lapangan ditempatkan di dalam stoples pemeliharaan dan di letakkan di nampan.

Pengamatan yang dilakukan terdiri dari mencatat jumlah dan jenis parasitoid yang muncul dari setiap stadia hama dan mencatat tanggal munculnya parasitoid tersebut. Kemudian dilakukan identifikasi parasitoid dengan menggunakan mikroskop stereo dan buku kunci identifikasi Hymenoptera (Goulet \& Huber, 1993). Selanjutnya, menghitung persentase parasitasi terhadap hama penggulung daun pisang. Rumus untuk menghitung persentase parasitasi adalah sebagai berikut:

$$
I P(\%)=\frac{N_{2}}{N_{1}} \times 100 \%
$$

Keterangan :

$\mathrm{N}_{1}$ = Jumlah telur, larva, atau pupa yang diambil dan dipelihara di laboratorium.

$\mathrm{N}_{2}$ = Jumlah telur, larva, atau pupa yang terserang parasitoid.

\section{HASIL DAN PEMBAHASAN}

Jenis-jenis Parasitoid yang ditemukan pada penelitian ini adalah sebagai berikut :

1. Parasitoid Cotesia sp. (Hymenoptera: Braconidae). Cotesia sp. adalah parasioid larva E. thrax. Parasitoid Cotesia sp. dapat muncul beberapa ekor dari seekor larva E. thrax yang terparasit. Parasitoid ini ditemukan di Kecamatan Natar Desa Tanjung Sari dan
Kecamatan Tanjung Bintang Desa Rejomulyo. Di Desa Tanjung Sari ditemukan sebanyak 12 ekor dan di Desa Rejomulyo ditemukan sebanyak 20 ekor.

Parasitoid Cotesia sp. diketahui dapat memarasit hama lain yaitu antara lain hama penggerek batang tebu, ulat jengkal, dan hama penggerek batang padi. Ratarata persentase parasitasi Cotesia sp. di Kecamatan Natar dan Tanjung Bintang masing-masing sebesar $1,67 \%$, sedangkan di Kecamatan Jati Agung tidak ditemukan sampel larva E. thrax yang terparasit Cotesia sp.

\section{Parasitoid Brachymeria sp. (Hymenoptera:} Chalcididae).

Brachymeria sp. (Hymenoptera; Chalcididae) ditemukan memarasit pupa E. thrax di Kecamatan Tanjung Bintang dengan rata-rata persentase parasitasi sebesar 25\%, Kecamatan Natar dan Jati Agung masingmasing sebesar $11,67 \%$ dan $10 \%$. Parasitoid Brachymeria sp. ditemukan dengan jumlah berkisar antara 2-24 ekor per inang. Parasitoid ini memiliki ciri umum yaitu tubuh berwarna hitam dengan tanda berwarna kuning, femur belakang membesar dan bergerigi. Parasitoid ini termasuk parasitoid gregarius atau berkelompok (Hasyim dkk., 2003).

Parasitoid Brachymeria sp. diketahui dapat memarasit hama lain seperti hama dari Famili Noctuidae (Plusia sp.), Hesperidae (Hidari sp.), dan Famili Pyralidae. Kadang-kadang parasitoid Brachymeria sp. menjadi hiperparasit pada Ichneumonidae yaitu Charops sp. di Papilio sp. (Kalshoven, 1981).

\section{Parasitoid Famili Tachinidae (A), Ordo Diptera.}

Parasitoid Famili Tachinidae (A) ditemukan di Kecamatan Natar Desa Candimas, Kecamatan Jati Agung Desa Karang Anyar dan Desa Rejomulyo, dan Kecamatan Tanjung Bintang Desa Sindang Sari, Purwodadi Simpang, dan Rejomulyo. Parasitoid ini ditemukan pada pupa E. thrax. Parasitoid ini ditemukan di Kecamatan Natar Desa Candimas sebanyak 1 ekor, di Kecamatan Jati Agung Desa Karang Anyar sebanyak 4 ekor, Desa Rejomulyo sebanyak 1 ekor, di Kecamatan Tanjung Bintang Desa Sindang Sari, Purwodadi Simpang, dan Rejomulyo masing-masing sebanyak 1 ekor. Parasitoid Tachinidae (A) muncul berkisar antara 1-2 ekor per inang.

Lalat Tachinidae memiliki ciri yaitu abdomen memiliki garis berwarna putih, pada abdomen, thorax dan kepala dipenuhi dengan rambut-rambut tebal, kemudian pada bagian mata terdapat garis berwarna putih (Gambar 1.a). Rata-rata persentase parasitasi Tachinidae (A) di Kecamatan Jati Agung dan Tanjung 


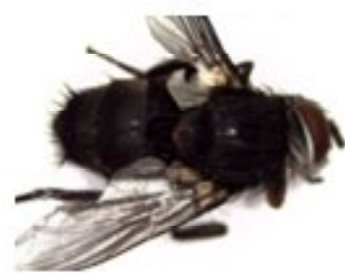

(a)

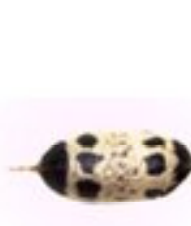

(b)

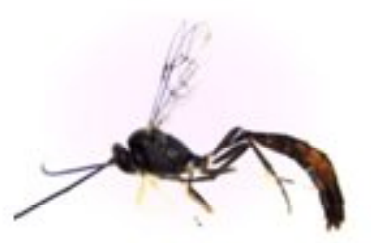

(c)

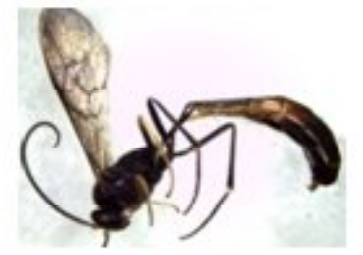

(d)

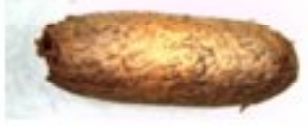

(e)

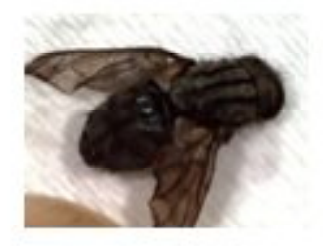

(f)

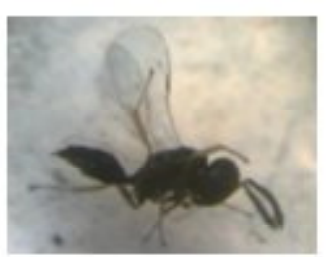

(g)

Gambar 1. (a) Imago parasitoid Famili Tachinidae (A), Ordo Diptera. (b) Pupa parasitoid Charops sp. (c) Imago parasitoid Charops sp. (d) Imago Parasitoid Ichneumonidae (B), Ordo Hymenoptera. (e) Pupa parasitoid Ichneumonidae (B), Ordo Hymenoptera (f) Imago parasitoid Famili Tachinidae (B), Ordo Diptera. (g) Imago Parasitoid Famili Pteromalidae, Ordo Hymenoptera.

Bintang masing-masing sebesar 5\%, sedangkan di Kecamatan Natar hanya sebesar $1,67 \%$.

\section{Parasitoid Charops sp. (Hymenoptera:} Ichneumonidae)

Charops sp. (Hymenoptera: Ichneumonidae) hanya ditemukan di Kecamatan Jati Agung yaitu di Desa Rejomulyo sebanyak 1 ekor, Desa Fajar Baru sebanyak 2 ekor, serta di Kecamatan Tanjung Bintang Desa Rejomulyo sebanyak 1 ekor. Parasitoid ini ditemukan pada larva E. thrax yang terparasit. Charops sp. merupakan parasitoid soliter karena keluar dari tubuh inang hanya satu ekor. Parasitoid ini mempunyai pupa yang sangat khas yaitu berwarna putih atau abu-abu dengan corak berwarna hitam lalu pupa tersebut menggantung keluar dari gulungan daun pisang karena memiliki benang yang cukup panjang (Gambar 1.b). Pada umumnya Famili Ichneumonidae memiliki ciri tubuh yang berukuran $13 \mathrm{~mm}$, berwarna hitam, antenanya panjang dan memiliki 16 ruas (Gambar 1.c) (Novianti, 2008). Rata-rata persentase parasitasi Charops sp. di Kecamatan Jati Agung sebesar 5\% dan Kecamatan Tanjung Bintang sebesar 1,67\%, sedangkan di Kecamatan Natar tidak ditemukan sampel larva $E$. thrax yang terparasit Charops sp.

\section{Parasitoid Ichneumonidae (B), Ordo Hymenoptera}

Parasitoid ini memiliki bentuk yang hampir sama dengan Charops sp., namun parasitoid ini memiliki ukuran tubuh yang sedikit lebih besar dibandingkan dengan Charops sp. (Gambar 1.d). Selain itu, parasitoid Famili Ichneumonidae ini memiliki pupa yang berwarna cokelat (Gambar 1.e) dan pupa tersebut menempel berada di dekat inang. Parasitoid ini ditemukan di Kecamatan Natar Desa Candimas sebanyak 4 ekor, Desa Tanjung Sari sebanyak 3 ekor, di Kecamatan Jati Agung Desa Rejomulyo sebanyak 5 ekor, Desa Fajar Baru sebanyak 2 ekor, di Kecamatan Tanjung Bintang Desa Sindang Sari sebanyak 1 ekor, Desa Purwodadi Simpang sebanyak 7 ekor, dan Desa Rejomulyo sebanyak 5 ekor. Rata-rata persentase parasitasi Ichneumonidae (B) di Kecamatan Natar dan Jati Agung masing-masing sebesar $11,67 \%$, sedangkan di Kecamatan Tanjung Bintang sebesar 21,67\%.

\section{Parasitoid Famili Tachinidae (B), Ordo Diptera}

Parasitoid Famili Tachinidae (B) hanya ditemukan di Kecamatan Natar yaitu di Desa Bumi Sari sebanyak 1 ekor. Parasitoid ini ditemukan pada pupa E. thrax. Pupa E. thrax yang terparasit akan berwarna hitam dan berlubang. Parasitoid Famili Tachinidae (B) tersebut memiliki ciri yang sama dengan parasitoid Famili Tachinidae (A) namun ukuran tubuh parasitoid tersebut lebih kecil dibandingkan dengan parasitoid Tachinidae (A) (Gambar 1.f). Rata-rata persentase parasitasi Tachinidae (B) di Kecamatan Natar dengan rata-rata persentase parasitasi sebesar 1,67\%, sedangkan untuk Kecamatan Jati Agung dan Tanjung Bintang tidak ditemukan sampel yang terparasit parasitoid tersebut. 
7. Parasitoid Xanthopimpla sp. (Hymenoptera: Ichneumonidae)

Xanthopimpla sp. adalah parasitoid yang ditemukan pada pupa E. thrax. Pupa yang terparasit parasitoid ini akan berwarna hitam. Parasitoid tersebut hanya ditemukan di Kecamatan Jati Agung yaitu di Desa Fajar Baru sebanyak 1 ekor. Parasitoid ini memiliki ciri yaitu warna tubuh berwarna kuning, dengan spotspot hitam pada bagian pronotum, abdomen, dan tungkai belakang. Selain itu, parasitoid ini memiliki ciri yaitu ukuran tubuh yang besar sekitar 10-14 mm, mempunyai antena yang panjang dengan 16 ruas, dan ovipositor panjang (Novianti, 2008). Rata-rata persentase parasitasi Xanthopimpla sp. di Kecamatan Jati Agung sebesar $1,67 \%$, sedangkan di Kecamatan Natar dan Tanjung Bintang tidak ditemukan sampel yang terparasit parasitoid tersebut.

\section{Parasitoid Famili Pteromalidae, Ordo Hymenoptera}

Parasitoid Famili Pteromalidae hanya ditemukan di Kecamatan Jati Agung yaitu di Desa Karang Anyar sebanyak 10 ekor. Parasitoid tersebut muncul 29-30 hari setelah inkubasi. Ciri parasitoid ini adalah memiliki ukuran tubuh $1 \mathrm{~mm}$, tungkai belakang memiliki tarsus berjumlah 5 segmen, coxa depan dan belakang memiliki ukuran yang sama, femur belakang tidak membesar, pronotum bagian dorsal tampak seperti kerucut, menyempit atau mengecil ke arah depan (Gambar 1.g). Parasitoid ini ditemukan pada pupa E. thrax yang terparasit. Rata-rata persentase parasitasi Pteromalidae di Kecamatan Jati Agung sebesar 3,33\%. Sedangkan di Kecamatan Natar dan Tanjung Bintang tidak ditemukan sampel yang terparasit parasitoid tersebut.

Rata-rata Persentase Parasitasi Semua Jenis Parasitoid dapat terlihat pada Tabel 1. Pada Tabel 1 terlihat bahwa persentase parasitasi tertinggi adalah di Kecamatan Tanjung Bintang dengan rata-rata sebesar $55,00 \%$, disusul dengan Kecamatan Jati Agung sebesar $36,67 \%$ dan Kecamatan Natar dengan rata-rata sebesar $28,33 \%$. Hal ini menunjukkan bahwa di Kecamatan Tanjung Bintang daya parasitasi terhadap hama

Tabel 2. Rata-rata persentase parasitasi semua jenis parasitoid pada hama E. thrax di tiga kecamatan.

\begin{tabular}{lc}
\hline \multicolumn{1}{c}{ Kecamatan } & $\begin{array}{c}\text { Rata-rata persentase } \\
\text { parasitasi } \pm \text { Sd }\end{array}$ \\
\hline Natar & $28,33 \pm 2,88$ \\
Jati Agung & $36,67 \pm 10,40$ \\
Tanjung Bintang & $55,00 \pm 13,22$ \\
\hline
\end{tabular}

penggulung daun pisang lebih tinggi dibandingkan dengan Kecamatan Jati Agung dan Natar.

Faktor yang menyebabkan tinggi rendahnya jumlah parasitoid antara lain faktor lingkungan seperti suhu, curah hujan, dan kelembaban, penyemprotan pestisida (Novianti, 2008), vegetasi sekitar tanaman pisang, dan kelimpahan populasi inang E. thrax (Riyanto et al., 2011). Faktor lingkungan seperti suhu, curah hujan, dan kelembaban, dan penyemprotan pestisida dapat mempengaruhi kelangsungan hidup parasitoid di lapangan (Novianti, 2008). Apabila curah hujan rendah, maka suhu akan lebih tinggi dan kelembaban akan rendah. Menurut Riyanto et al. (2011), parasitoid lebih efektif melakukan metabolisme pada suhu yang lebih tinggi, artinya pada suhu tinggi parasitoid mempercepat aktivitas parasitoid dalam memarasit inang. Selanjutnya vegetasi tanaman yang berada di sekitar tanaman pisang juga dapat mempengaruhi jumlah parasitoid di lapangan, karena parasitoid mampu bertahan hidup apabila mendapatkan asupan makanan dari tumbuhan lain yang berupa nektar.

Sampel hama penggulung daun pisang yang diambil dari Kecamatan Tanjung Bintang pada umumnya sampel dari tanaman pisang yang tumbuh di pekarangan rumah atau kebun campuran dengan berbagai vegetasi tanaman seperti tanaman mangga, jambu, rambutan, durian, singkong, jagung, cabai dan gulma. Hal ini dapat memungkinkan parasitoid untuk mampu mempertahankan diri dengan mendapatkan asupan makanan yang cukup yaitu berupa nektar. Sedangkan sampel hama penggulung daun pisang yang diambil di Kecamatan Natar, pada umumnya sampel dari tanaman pisang dengan vegetasi sekitar tanaman adalah tanaman padi (sawah). Hal ini memungkinkan bahwa terjadinya perubahan adaptasi akibat penggunaan insektisida yang intensif dalam mengendalikan hama, sehingga dapat membunuh musuh alami yang ada. Oleh karena itu, persentase parasitasi di Kecamatan Natar lebih kecil dibandingkan Kecamatan Tanjung Bintang.

Pada saat pengambilan sampel di lapangan yaitu pada Bulan Desember 2013, curah hujan di Kecamatan Tanjung Bintang sebesar 354,0 mm dan di Kecamatan Natar sebesar 309,0 mm. Hal ini menunjukkan bahwa curah hujan di Kecamatan Tanjung Bintang lebih tinggi dibandingkan dengan Kecamatan Natar. Secara teori, semakin tinggi curah hujan maka kelembaban udara akan semakin tinggi, sedangkan suhu akan semakin rendah. Oleh karena itu, tingkat parasitasi yang terjadi di Kecamatan Tanjung Bintang lebih besar dibandingkan Kecamatan Natar, pada curah hujan yang lebih tinggi, kelembaban udara tinggi dan suhu yang lebih rendah. Hal ini menunjukkan bahwa faktor lingkungan seperti 
suhu, curah hujan, dan kelembaban tidak berpengaruh terhadap perbedaan tingkat parasitasi yang terjadi di Kecamatan Tanjung Bintang dan Natar.

Faktor lain yang menyebabkan perbedaan tingkat parasitasi antara Kecamatan Tanjung Bintang, Jati Agung dan Natar adalah karena populasi hama penggulung daun pisang di Kecamatan Tanjung Bintang lebih banyak dibandingkan dengan Kecamatan Natar dan Jati Agung sehingga kematian yang disebabkan oleh musuh alami semakin tinggi. Menurut Susilo (2007), semakin tinggi tingkat populasi hama maka semakin tinggi pula tingkat kematian hama tersebut akibat musuh alami atau daya kendali musuh alami semakin tinggi pada populasi hama yang semakin padat. Hal ini disebut dengan density dependent (terpaut kepadatan). Density dependent merupakan salah satu syarat terjadinya pengendalian hayati. Pengendalian hayati akan berjalan dengan baik apabila memenuhi dua syarat yaitu density dependent (terpaut kepadatan) dan self sustenance (keberlanjutan diri).

Keanekaragaman jenis parasitoid dapat dipengaruhi oleh ketinggian tempat, faktor lingkungan seperti suhu, curah hujan, dan kelembaban (Riyanto et al., 2011), praktek budidaya (Susiawan\&Yuliarti, 2006), dan vegetasi tanaman (Brewer \& Elliot, 2004 dalam Riyanto et al., 2011). Menurut Brewer \& Elliot, (2004 dalam Riyanto et al., 2011) menyatakan bahwa keanekaragaman tumbuhan yang tumbuh berada di sekitar tanaman budidaya dapat mempengaruhi kehadiran parasitoid kutu daun. Dengan demikian dapat dimungkinkan bahwa vegetasi yang berada di sekitar tanaman pisang dapat mendukung keanekaragaman parasitoid hama penggulung daun pisang. Kecamatan Tanjung Bintang terletak pada ketinggian $74 \mathrm{~m} \mathrm{dpl,}$ Kecamatan Jati Agung terletak pada ketinggian 79 m dpl, sedangkan Kecamatan Natar terletak pada ketinggian $92 \mathrm{~m}$ dpl. Hasil penelitian menunjukkan di Kecamatan Jati Agung ditemukan 6 jenis parasitoid sedangkan di Kecamatan Natar dan Tanjung Bintang masing-masing ditemukan sebanyak 5 jenis parasitoid. Hal ini menunjukkan bahwa ketinggian tempat tidak berpengaruh terhadap jumlah jenis parasitoid di tiga kecamatan tersebut.

Curah hujan di Kecamatan Tanjung Bintang sebesar 354,0 mm dan di Kecamatan Natar sebesar 309,0 mm. Hal ini menunjukkan bahwa curah hujan di Kecamatan Tanjung Bintang lebih tinggi dibandingkan dengan Kecamatan Natar. Secara teori, semakin tinggi curah hujan maka kelembaban udara akan semakin tinggi, sedangkan suhu akan semakin rendah. Berdasarkan data curah hujan yang telah diperoleh, menunjukkan bahwa faktor lingkungan tersebut tidak mempengaruhi keanekaragaman jenis parasitoid di Kecamatan Natar dan Tanjung Bintang.

\section{KESIMPULAN}

Kesimpulan yang dapat diperoleh dari penelitian ini adalah Parasitoid yang ditemukan di Kecamatan Natar, Jati Agung, dan Tanjung Bintang yaitu Cotesia sp., Brachymeria sp., Famili Tachinidae (A), Charops sp., Famili Ichneumonidae (B), Famili Tachinidae (B), Xanthopimpla sp., dan Famili Pteromalidae. Berbagai jenis parasitoid tersebut sangat potensial, daya parasitasi dapat mencapai $55 \%$ seperti yang terjadi pada Kecamatan Tanjung Bintang.

\section{DAFTAR PUSTAKA}

BPS dan Bappeda Provinsi Lampung. 2007. Lampung Dalam Angka 2007. Lampung.

Direktorat Perlindungan Perkebunan \& Direktorat Jenderal Bina Produksi Perkebunan Departemen Pertanian. 2002. Musuh Alami, Hama dan Penyakit Tanaman Lada. Proyek Pengendalian Hama Terpadu Perkebunan Rakyat. Jakarta.

Goulet, H. dan J.T. Huber. 1993. Hymenoptera of the World: An Identification Guide to Families. Canada Communication Group. Ottawa. Canada.

Harlinawati, Y. 2006. Terapi Jus Untuk Rematik dan Asam Urat. Puspa Swara. Jakarta.

Hasyim, A., Kasimar, dan K.Nakamura. 2003. Mortalitas Stadia Pradewasa Hama Penggulung Daun Pisang Erionota thrax (L) yang Disebabkan oleh Parasitoid. Sumatera Barat. J.Hort. 13(2): 114-119.

Kalshoven, L.G.E. 1981. The Pests of Crops in Indonesia. (Rev. And Transl: P.A. van Der Laan). PT. Ichtiar BaroeVan Hoeve. Jakarta. $701 \mathrm{pp}$.

Novianti, F. 2008. Hama Penggulung Daun Pisang Erionota thrax Linnaeus (Lepidoptera: Hesperidae) Dan Musuh Alaminya Di TempatTempat Dengan Ketinggian Berbeda. Skripsi. Fakultas Pertanian IPB. Bogor. 43 hal.

Riyanto, S.Herlinda, C.Irsan, dan A. Umayah. 2011. Kelimpahan dan Keanekaragaman Spesies Serangga Predator dan Parasitoid Aphis gossypii di Sumatera Selatan. Palembang. J.HPT. 11(1): 57-68. 
Satuhu, S. dan A.Supriyadi. 2007. Pisang Budidaya, Pengolahan, dan Prospek Pasar. Penebar Swadaya. Jakarta.

Susiawan, E. dan N. Yuliarti. 2006. Distribusi dan Kelimpahan Parasiotid Telur, Telenomus spp di Sumatera Barat: Status dan Potensinya Sebagai Agens Pengendali Hayati. Padang. J. Entomol. Indon. 3(2):104-113.
Susilo, F.X. 2007. Pengendalian Hayati Dengan Memberdayakan Musuh Alami Hama Tanaman. Graha Ilmu. Yogyakarta. 